ПРЕГЛЕДНИ ЧЛАНЦИ

ОБЗОРНЫЕ СТАТЬИ

REVIEW PAPERS

\title{
CHARACTERISTICS OF
} POLYURETHANE AND ELASTOMER PARTS FOR SHOE INDUSTRY PRODUCED BY LIQUID INJECTION MOLDING TECHNOLOGY

\author{
Radovan M. Karkalića , Jovan R. Radulovićb, \\ Dalibor B. Jovanovićc \\ a University of Defence in Belgrade, Military Academy, Belgrade, \\ Republic of Serbia, \\ e-mail: radovan.karkalic@va.mod.gov.rs, \\ ORCID iD: Dhttp://orcid.org/0000-0002-8074-7264 \\ ${ }^{\mathrm{b}}$ Ministry of Defence of the Republic of Serbia, Military Technical \\ Institute, Belgrade, Republic of Serbia, \\ e-mail: jovan.r.radulovic@gmail.com, \\ ORCID iD: (1)http://orcid.org/0000-0001-9214-8093 \\ ${ }^{\mathrm{c}}$ Serbian Armed Forces, Technical Test Centre, Belgrade, \\ Republic of Serbia, \\ e-mail:jovcadach@hotmail.com, \\ ORCID iD: (i)http://orcid.org/0000-0002-3484-8638
}

http://dx.doi.org/10.5937/vojtehg65-10543

FIELD: Chemical Technology ARTICLE TYPE: Review Paper ARTICLE LANGUAGE: English

\section{Abstract:}

This paper presents the characteristics of the materials used in footwear industry, with a particular emphasis on polyurethane materials for making soles. The role, purpose and design of soles are also discussed, as well as the requirements this part of the shoe should satisfy.

The manufacturing of polyurethane soles by liquid injection molding technology (LIM technology) is described, namely its two procedures. In the first one, the sole is obtained by pouring polyurethane into an open tool, and the second one is direct injection of polyurethane on the shoe upper in a closed tool, thus completing the production of finished footwear. 
The results of testing the specimens cut out from three sole samples show that almost all quality requirements under technical specifications for this part of the shoe are met. The tested sole samples do not meet the formal requirements for tensile strength, although the values of this characteristic in a sample made of a polyurethane-rubber combination and a sample made of elastomeric material are very close to the set quality requirements.

Key words: polymeric materials, shoe soles, liquid injection molding technology, quality.

\section{Introduction}

Footwear, in one form or another, has been around for a long time. In ancient times, the simplest way to protect the foot was to use handy materials such as bark, leaves, grass and vines wrapped around the foot. The drawings in the caves of Spain originating from more than 15000 years ago show people with their feet wrapped in animal skin and fur. But since the time of ancient Rome to the present day, many types of footwear have survived, indicating that there were much more types of footwear than anyone could have expected. Therefore, the intensive development of production technology of footwear continues today, due to technical and technological solutions in the production of a variety of footwear (Groover, 2001).

In terms of technology, production is the application of physical and chemical processes in order to change the geometry, properties and/or appearance given to raw materials to produce parts or products. Production also includes completing more parts to create the product.

There are different types of materials used in footwear industry. The main materials used for making footwear are leather, synthetic polymers, rubber, plastics, textile materials, knitted materials, wood, cork and in some cases metal materials (http://www.publications.theseus.fi).

Polymers have become the main specialized materials for footwear industry. Simply put, polymer is a chemical compound composed of small molecules arranged in a simple structure to form larger molecules, or to the full definition, this is a chemical compound or a mixture of compounds obtained by polymerization and consisting essentially of repeating structural units (http://www.merriam-webster.com).

The importance of polymers in footwear industry is a result of efforts to use only the highest quality raw materials. This is very important because it is directly related to human health. This material is almost always in contact with human skin. Manufacturers of both plastic and elastomeric materials co-operate with manufacturers of footwear in order to develop new materials that must meet the requirements of today's shoes (Melo, Cavaco, 2012). 
In short, footwear consists of an upper and a lower part. The footwear parts are shown in Figure 1. For the production of shoe uppers, leather is commonly used. Different polymeric materials are used to create lower parts of shoes - soles.

The lower part usually consists of the sole, the insole and the tread. To create soles, high-quality leather (vegetable rack) is used, while the production of insoles applies slightly less quality leather (vegetable part). For tread soles, different polymeric materials are commonly used. Polymeric soles should satisfy a number of requirements in order to achieve the best possible protection of footwear, being the footwear part in direct contact with the ground on which a person moves.

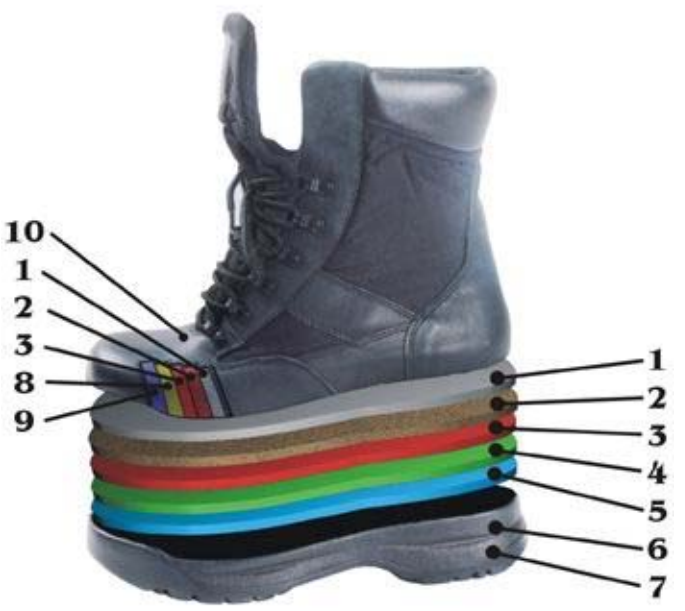

1 - Setup

2 - Thermal insulation

3 - Polyurethane membranes

4 - Rubber membrane protection

5 - Assembly insole

6 - Polyurethane part of the sole

7 - Tread rubber part of the sole

8 - Felt

9 - Thermoplastic eaves

10 - Boot/shoe face, genuine leather

Figure 1 - Components of shoes (boots)

Puс. 1 - Составные части обуви (ботинка)

Слика 1 - Саставни делови обуће (чизме)

Soles, which are in contact with the ground, should meet the following requirements:

- Good adhesion to various substrates (soil, paving, asphalt, etc.)

- Good flexibility during walking,

- Low wear, which ensures a long service life of shoes,

- Good mechanical characteristics, which allow the strength and flexibility of the sole, depending on the physical and mechanical properties of the material used (tensile strength, elongation, etc.)

- Resistance to splitting, which may occur in contact with sharp objects (stones, nails, etc.) 
- Slight, almost insignificant slipping on wet surfaces, ice and other slippery surfaces,

- Structural solution that enables easy separation from water, mud, stones, snow and reduce slippage,

- Medium hardness material that provides flexibility and comfort when walking, with less fatigue,

- Good and easy adhesion to the upper with the highest possible soleupper adhesion force when using standard adhesives,

- Low weight, and low-density materials,

- Tightness of the sole-upper bond.

\section{Polymeric materials for footwear industry}

It is considered that the durability of a material is directly proportional to its density. This attitude has a lot of exceptions, but it can be accepted as a simplified rule shown graphically in Figure 2.

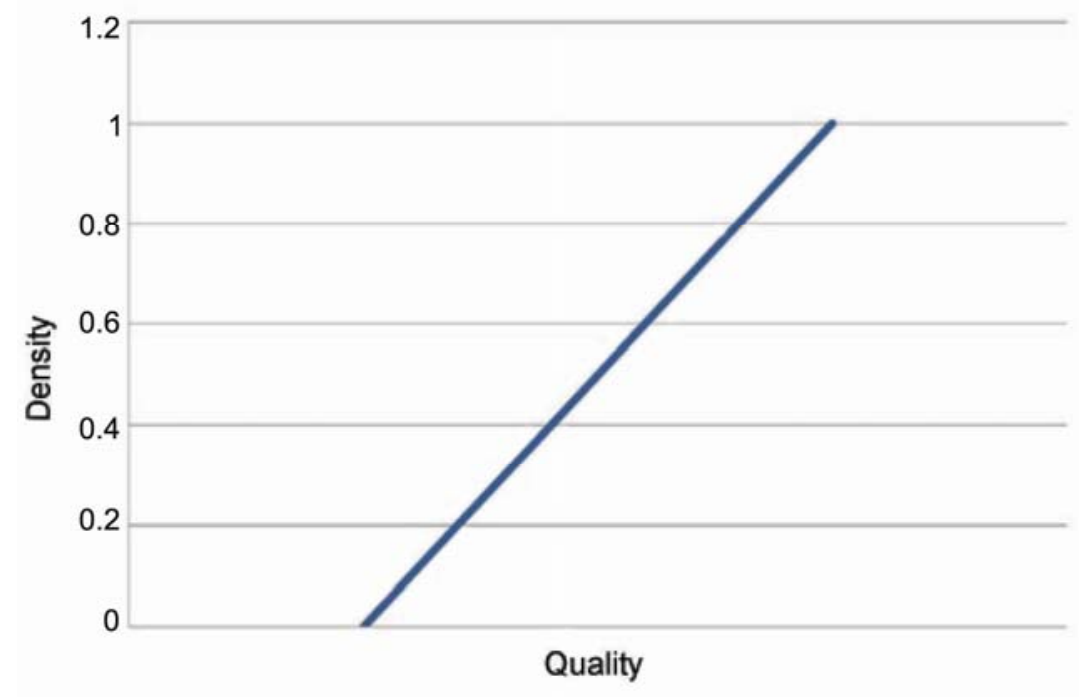

Figure 2 - Simplified quality-density dependence

Puc. 2 - Упрощенная взаимозависимость качество-плотность

Слика 2 - Упрошћена зависност квалитет-дустина

A compact material of a relative density value of 1 or greater (relative density is the ratio of material density and water density) practically has no holes in it and is a "complete" material feature. If we look at, for example, abrasion resistance - particularly sole abrasion, this material will withstand 
an abrasive contact for a long time because there is no place on the surface where material abrasion could begin.

A material the density of which is lower than the density of water must have a cell structure. Cells can be larger or smaller in size, they may be more or less connected to each other, i.e. materials may have open or closed cells. Figure 3 shows open cell (magnification 15x) and closed cell (magnification $35 \times$ ) expanded materials - materials with a cellular structure (https://www.linkedin.com).
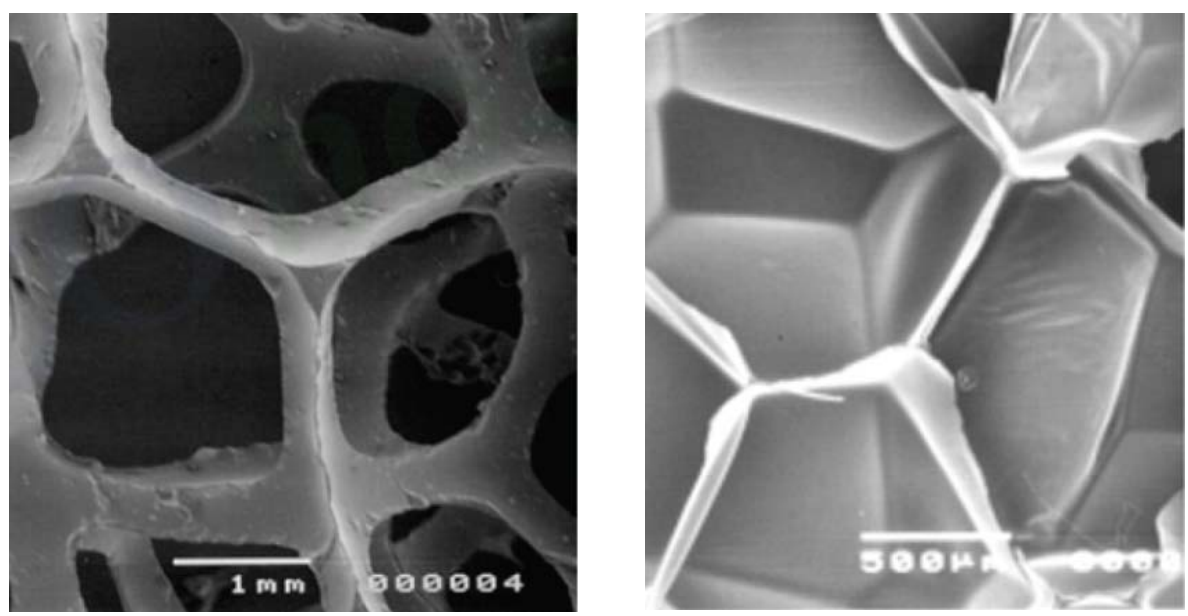

Figure 3-Open cell (a) and closed cell (b) expanded materials

Puc. 3 - Открытые ячейки (а) закрытые ячейки (б) экспандированного материала Слика 3 - Отворене ћелије (а) и затворене ћелије (б) експандираног материјала

The essence of the reduction in density of a material whose relative density is always greater than 1 is nothing more than making a cellular structure in which there are many gaseous components. It is important that there should be a lot of empty space (filled with a gas, regardless of whether it is air, carbon dioxide, or something else), so that the whole structure has less mass than water and therefore lower relative density. For example, if the abrasion resistance of different materials (from compact materials to materials of lower density) is shown in the form of a diagram, it will not be a straight line as in the simplified dependency, but more like a so-called point cloud, as shown in Figure 4. 


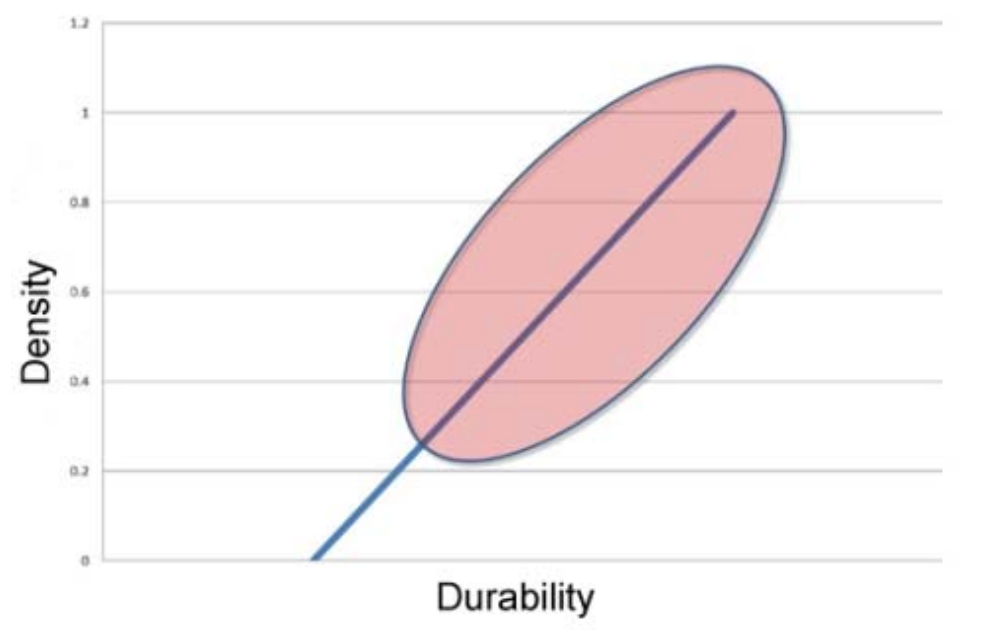

Figure 4 - The so-called cloud quality - density dependence

Puc. 4 - «Облачная» взаимозависимость качество-плотность Слика 4 - Тзв. облак зависности квалитет-густина

If the aforementioned procedure is repeated for other features, there will be a similar graphical dependency. These data are the basis for assessing the quality of the materials for making shoe soles.

When it comes to compact materials, it is necessary to consider leather and vulcanized elastomeric materials. Although soles made of compact leather have their advantages, they also have certain drawbacks (lack of durability, decreased water resistance, poor insulation, problems with the design, etc.). Vulcanized elastomer materials have begun to be used as a material for soles about 50 years ago and represent a major technological achievement - rubber soles are waterproof and allow the foot to be warm and dry even in winter months (Mills, 2007).

The entire group of compact polyurethane materials (for example, thermoplastic polyurethanes) may have the characteristics listed as good features of the two aforementioned compact materials.

Polyurethanes are an important class of polymers resulting from a polycondensation reaction between different polyols, isocyanates and additives, which allows obtaining a wide range of polymers of various properties and applications.

As for durability, compact polyurethanes have a significant advantage in relation to compact materials, vulcanized rubber and leather, which is visible in Figure 5. 


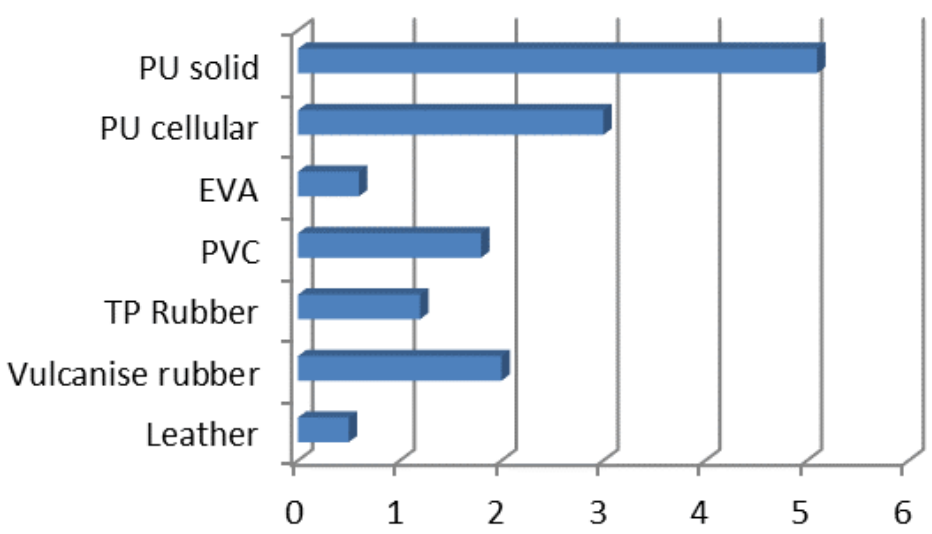

Figure 5 - Specific durability of materials for shoe soles Pис. 5 - Удельная прочность материалов для подошв обуви Слика 5 - Специфична трајност материјала за ђонове обуће

As far as materials of lower density are concerned, cellular, ie. expanded polyurethanes cover a wide range of density, starting from a compact high density material (density of about $0.9 \mathrm{~g} / \mathrm{cm}^{3}$ to $1 \mathrm{~g} / \mathrm{cm}^{3}$ ), through a common density of $0.6 \mathrm{~g} / \mathrm{cm}^{3}$ to $0.5 \mathrm{~g} / \mathrm{cm}^{3}$ for high-quality soles, from $0.5 \mathrm{~g} / \mathrm{cm}^{3}$ to $0.4 \mathrm{~g} / \mathrm{cm}^{3}$ for thicker and less quality soles for women's shoes, from $0.4 \mathrm{~g} / \mathrm{cm}^{3}$ to $0.3 \mathrm{~g} / \mathrm{cm}^{3}$ for lower quality soles for home shoes or slippers, to low density of $0.3 \mathrm{~g} / \mathrm{cm}^{3}$ to $0.2 \mathrm{~g} / \mathrm{cm}^{3}$ for insoles of sports shoes or flexible soles for comfortable footwear.

People often stop wearing particular shoes because they are not modern any more, but due to polyurethane durability, they still have value as used goods. Even if thrown away as waste, such footwear may be used with other solid waste as a fuel source.

Different polymeric materials (plastics, rubber materials, a combination of elastomeric materials - plastic materials, expanded materials, etc.) are used for sole production. The main reason to use the mentioned materials is the fulfilment of a large number of requirements; however, costs of both materials and the production technology must be taken into account.

In practice, the most commonly used elastomer materials are natural rubber (NR), thermoplastic rubber (TPR), styrenbytadien rubber (SBR) and bytadienakrylonitrile rubber (NBR).

The most commonly used plastic materials are polyurethane (PUR) and polyvinyl chloride (PVC), etc. 
Lately, the soles of polyurethane systems, combined rubberpolyurethane soles, have been used for making sports shoes and boots. In addition to having the proper physical and mechanical characteristics, the lower part of the combined material (rubber) provides good adhesion to the substrate, and the upper part (polyurethane) provides the necessary strength of the bond with rubber and leather uppers. Often the upper part of the polyurethane mid-sole is constructively resolved so that, besides cementing, it is possible to stitch the sole and the upper, thus resulting in a stronger sole-upper adhesion force and a longer service life. In sports shoes, weight, design and elasticity are significant, while in protective footwear the emphasis is on comfort, durability and protection.

\section{Polyurethane systems}

Polyurethanes are plastic materials obtained by combining polyol and isocyanate; the basic chemical process of this system was discovered by Otto Bayer in 1937(http://www.polyurethanes.org).

Polyurethanes are prepared by the exothermic reaction between an alcohol with two or more reactive hydroxyl $(-\mathrm{OH})$ groups per molecule (diols, triols, polyols) and isocyanates, which typically have two or more reactive isocyanate groups (-NCO) per molecule (e, diisocyanates, polyisocyanates). The basic process is the reaction of the polyurethane system; for example, a diisocyanate with a diol shown in the following Figure (Bayer, 1947, pp.257-272).

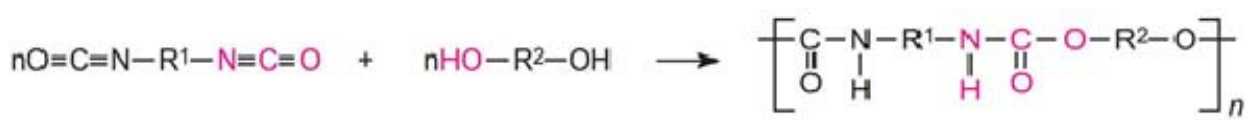

Figure 6 - The basic reaction of the polyurethane system

Puс. 6 - Базовая реакция полиуретановой системы

Слика 6 - Основна реакција полиуретанских система

The group obtained by the reaction of these two molecules is known as the "urethane bond" and represents an important part of the polyurethane molecule.

For the production of polyurethane shoe soles, the mentioned principle is used to control systems that comprise two components. One component is a polyol with terminal hydroxyl groups, and the other is a multifunctional diisocyanate. If necessary, color is added to the polyol component (Rosato et al, 2000). 
Polyurethane systems for shoe soles can be based on polyester or polyether polyol or a polyol. These two systems have specific features; a choice of a system depends on the end use of shoes with such soles.

Polyester systems are, generally speaking, more reactive due to the fact that they are solid at room temperature and it is necessary to warm them up prior to use. Due to the fact that it is necessary to apply a high temperature in order to maintain polyester polyols in a liquid form, the manipulation of this component is somewhat difficult. As the system expands, material is heated and the temperature of the tool is reduced as well as the curing time. However, soles based on polyester systems are less durable and are subject to biological influence, ie. the effects of bacteria and fungi. These features are quite adequate for the footwear market with fastchanging designs and models (Yutaka et al, 2009, pp.3722-3742).

The largest number of isocyanates to be used for the production of polyurethanes have two or more isocyanate groups per molecule. The most commonly used isocyanates are aromatic diisocyanates, methyl benzene diisocyanate (better known as toluene diisocyanate TDI) and methylene diphenyl diisocyanate MDI (Urethanes Technology International, 2015).TDI was developed first, but is now mainly used for the production of flexible foam of low density for furniture industry (pillows, etc.). A mixture of diisocyanates known as TDI consists of two isomers (Figure 7):<smiles>Cc1ccc([N+](=O)[O-])cc1[N+](=O)[O-]</smiles><smiles>Cc1c([N+](=O)[O-])cccc1[N+](=O)[O-]</smiles>

Figure $7-T D I$ isomers

Puc. 7 - Изомеры TDI

Слика 7 - Изомери TDI

MDI is something more complex and allows a wider range of opportunities in polyurethane production in terms of technologies and end products. A mixture of MDI diisocyanate is commonly used for the production of rigid expanded materials. MDI includes the following diisocyanates, shown in Figure 8. 


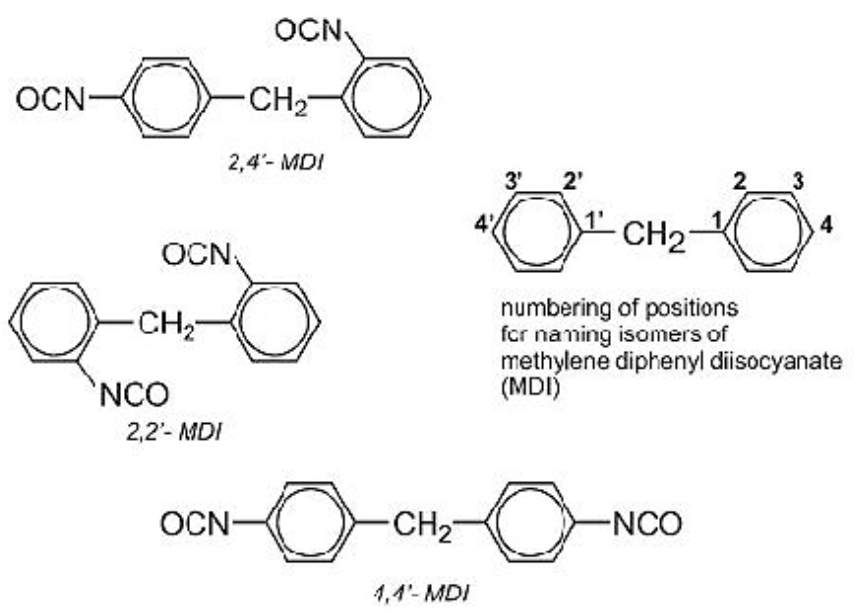

Figure $8-A$ mixture of $M D I$

Puc. 8- Смесь MDI

Слика 8-Cмеша MDI

The characteristics of the polyurethane material used for LIM (Liquid Injection Molding) technology for making soles are given in Table 1.

Table 1 - Characteristics of the polyurethane material for LIM technology

Таблица 1 - Характеристики полиуретанового материала для технологии LIM

Табела 1 - Карактеристике полиуретанског материјала за ЛИМ технологију

\begin{tabular}{|l|c|c|}
\hline \multicolumn{1}{|c|}{ Characteristics } & Testing method & Value \\
\hline Density, g/cm ${ }^{3}$ & DIN 53420 & 0.62 \\
\hline Tensile strength, MPa & DIN 53455 & 10 \\
\hline Tensile elongation, \% & DIN 53455 & 420 \\
\hline Tear resistance, kN/m & DIN 53515 & 20 \\
\hline Abrasion(mass loss), mg & DIN 53516 & 30 \\
\hline Hardness, H'Sh A & DIN 53505 & 70 \\
\hline Resistance to folding & P-2 on 25C & $>20.000$ foldings \\
\hline $\begin{array}{l}\text { Adhesion force of joint PUR } \\
\text { sole-leather, N/cm }\end{array}$ & DIN 53530 & $50 \pm 10$ \\
\hline
\end{tabular}




\section{The production of polyurethane soles by liquid injection molding technology}

Soles of polyurethane systems are produced by liquid injection molding (LIM) technology. It is an industrial production method that forms raw materials into a variety of products of a wide range of applications. This process includes weighing, mixing and pouring two liquid plastic components (http://www.chemtrend.com).

This technology is different from the standard process of reaction injection molding because it is based more on mechanical agitation than on forced stirring under pressure. In this way, a large number of parts with different characteristics can be produced.

Figure 9 shows the scheme of the equipment for liquid injection molding technology as well as the dependence of the viscosity on shear rate at characteristic locations of this equipment(http://www.xiameter.com).

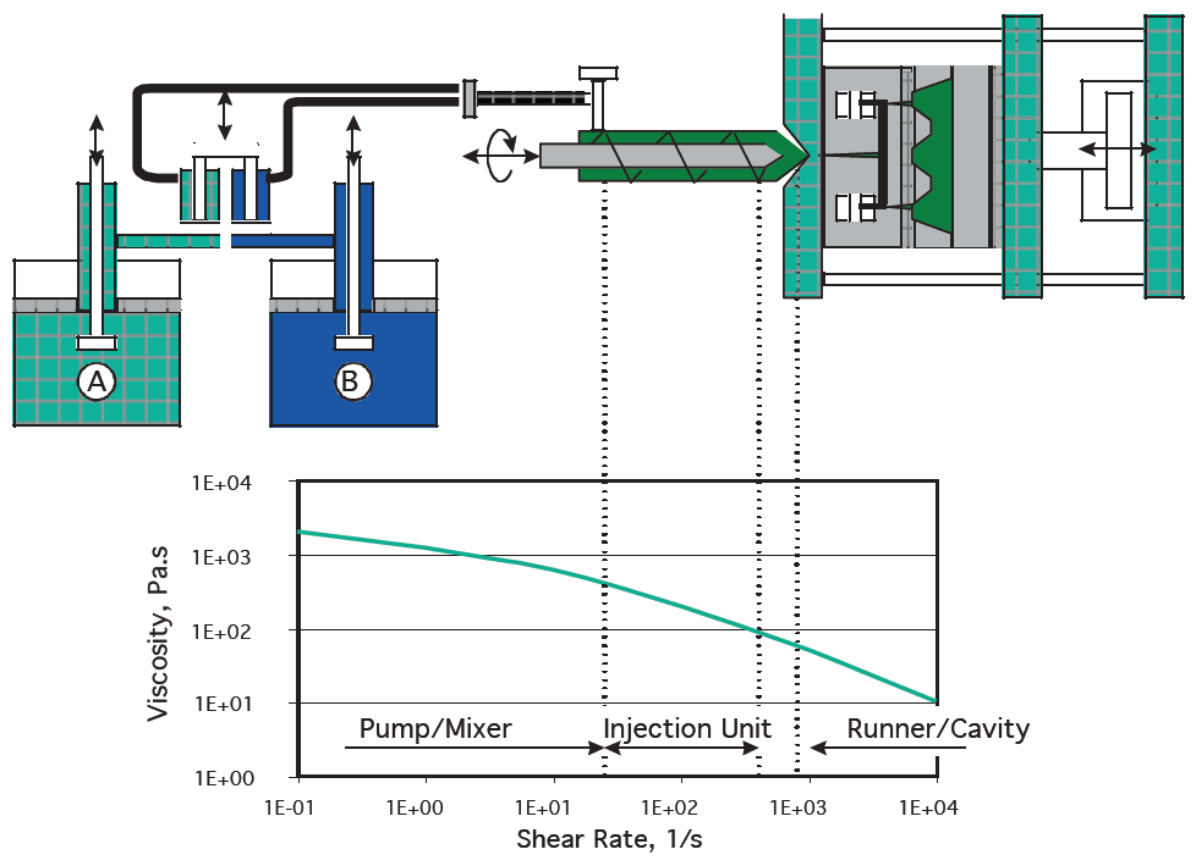

Figure 9 - Scheme of the equipment for injection molding technology Puc. 9 - Схема оборудования для изготовления подошвы методом литья под давлением Слика 9 - Шема опреме за технологију ињекционог обликовања 
A photo of one type of an LIM technology machine is shown in Figure 10.

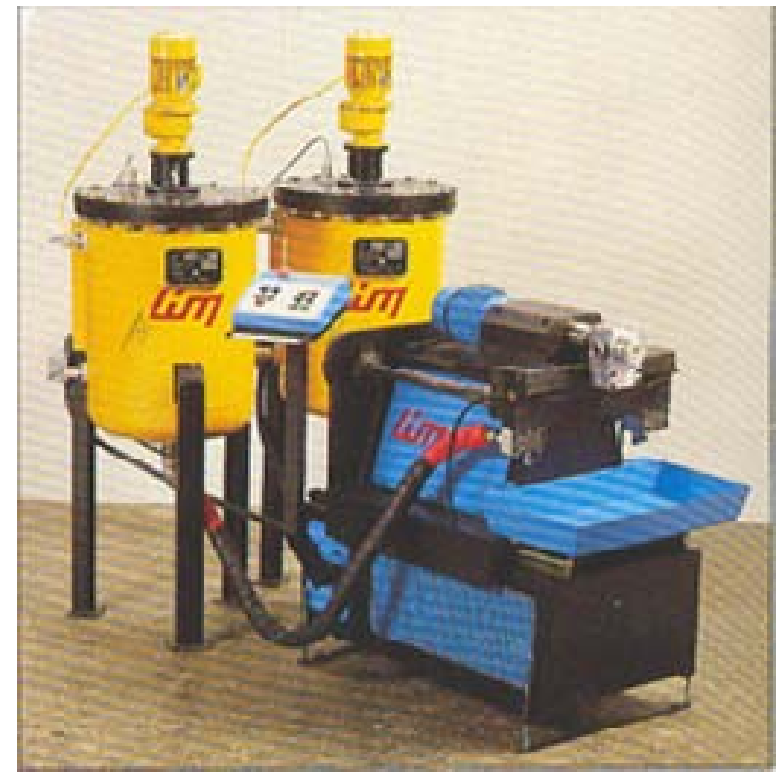

Figure 10 - One of the LIM technology machines Puc. 10 - Машина применяемая в LIM технологии Слика 10 - Једна од машина за ЛИМ технологију

The polyol component and the isocyanate component are mixed in the appropriate ratio and the resulting mixture is injected into a suitable tool mounted on an injection press. In these conditions, at the same time, the finished product is molded and the curing process occurs in the tool of proper temperature for a certain period of time. The tool is most frequently made of aluminium and its alloys.

For the production of polyurethane soles by the mentioned technology, two methods are commonly appled.

In the first method, a homogenised liquid mixture flows into the heated outdoor tool under low pressure, the tool closes, and after a certain time period, the tool opens and a sole is removed from the tool. Figure 11 shows the casting of the mixture into the tool, and Figure 12 - the extraction of the sole from the tool. This procedure produces lightweight soles which can be used for shoes, boots and sport shoes. Thus obtained polyurethane soles have better wear resistance than rubber soles and the possibility of colouring in the mass, so that they can be attached to nearly all kinds of shoes (http://www.essentialchemicalindustry.org). 


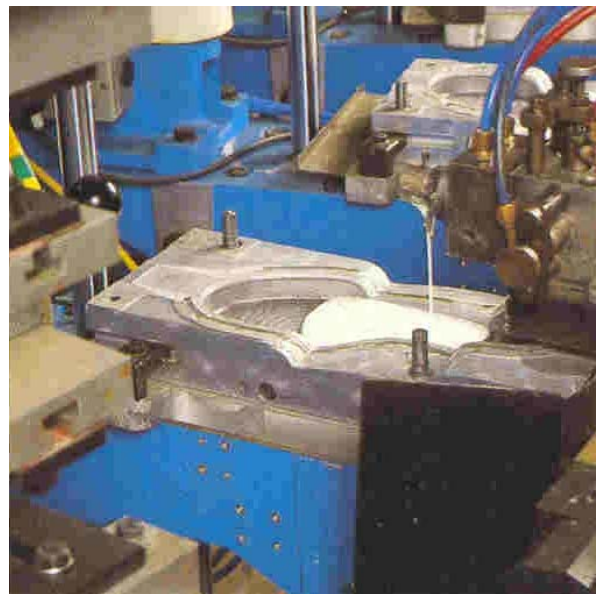

Figure 11 - Casting mixture into the tool Figure

Рис. 11 - Заливка формм смесью Слика 11 - Уливање смеше у алат

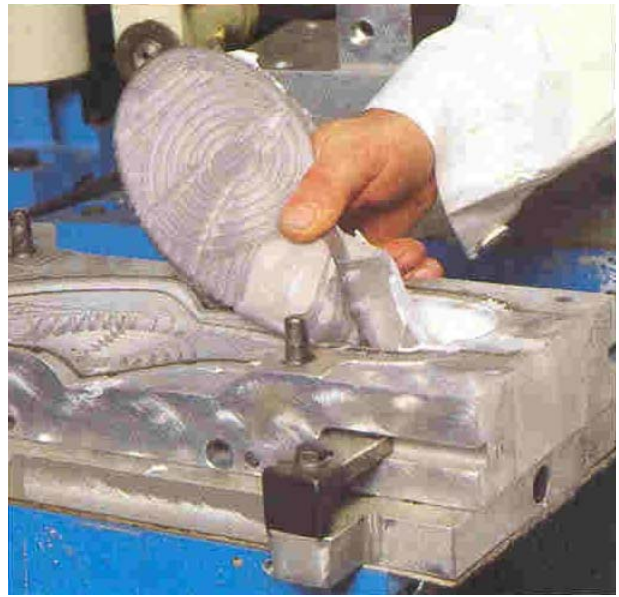

12- Removing the sole from the tool Puc. 12 - Извлечение подошвы из формы Слика 12 - Вађење ђона из алата

In Figure 13, soles of different designs are shown. Soles are attached to uppers by gluing and sometimes also by stitching to obtain higher bond strength.

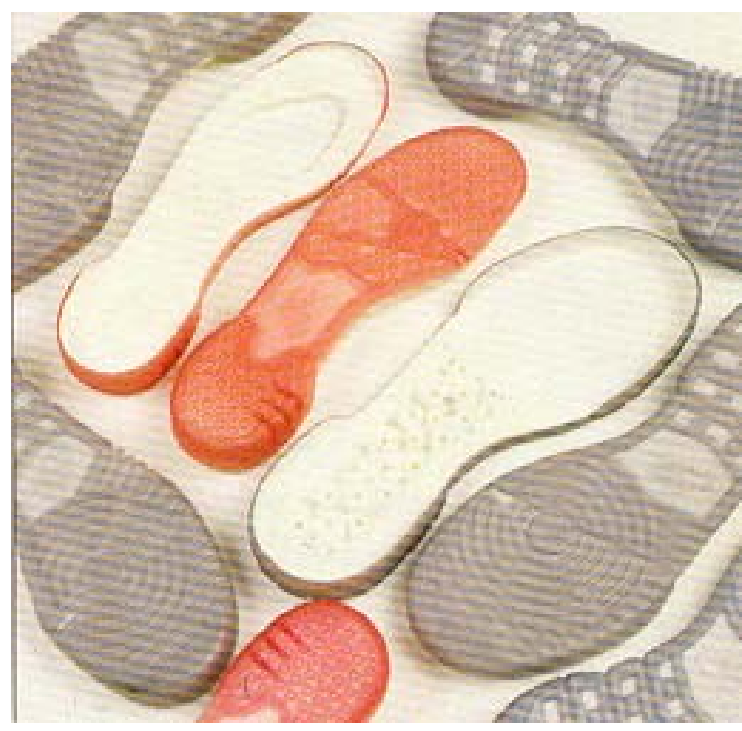

Figure 13 - Polyurethane soles obtained by technology

Puc. 13 - Полиуретановая подошва, изготовленная методом LIM Слика 13 - Полиуретански ђонови добијени ЛИМ технологијом 
The second method is a method of direct injection of a polyurethane sole onto the shoe upper. Figure 14 shows the basic stages of this process in the manufacture of boots.

A boot upper placed onto the upper movable mold part slowly descends to the lower embossing tool (left top). After setting the boot upper onto the lower mold part (right top), the tool closes completely and the polyurethane system is injected to form a sole (right bottom). Depending on the applied PUR system, the size of the sole and the equipment used, the innjection time is from $15 \mathrm{~s}$ to $40 \mathrm{~s}$. The temperature of the tool and the curing time also depend on the system used and the size of the polyurethane sole. The tool temperature is usually from $25^{\circ} \mathrm{C}$ to $95{ }^{\circ} \mathrm{C}$ and the time of cementing the PUR sole with the boot upper in a compact unit is from 5 minutes to 8 minutes. After this time, the tool is opened and the boot is removed from the tool in about 10 seconds; the tool is then ready for the next cycle of this process (left bottom).

PUR soles are manufactured by the described procedures with equipment that may have dozens of complete tools and a system for injecting polyurethane system(http://www.medical.saint-gobain.com).

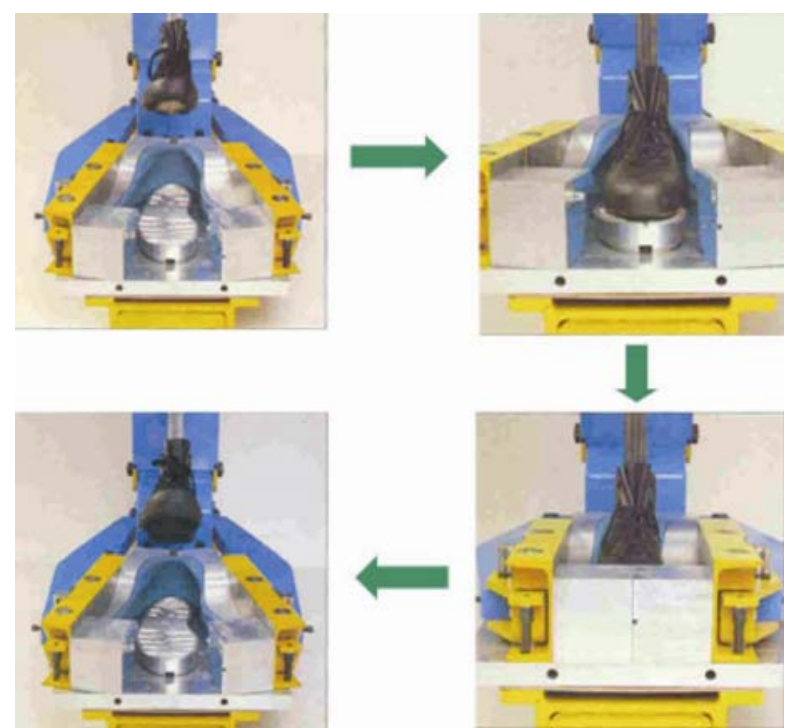

Figure 14 - Four stages of the process of direct polyurethane sole injection onto the boot upper

Puc. 14 - Четыре этапа процесса прямого литья полиуретановой подошвы на верх ботинка

Слика 14 - Четири фазе поступка директног убризгавања полиуеранског ђона на горњиште чизме 


\section{Quality requirements for soles}

The quality requirements for boot soles with leather uppers in accordance with relevant technical specifications are listed in Table 2.

Table 2 - Quality requirements for boot soles

Таблица 2 - Требования к качеству подошвы для обуви высокого покроя Табела 2 - Захтеви квалитета ђонова за чизме

\begin{tabular}{|l|c|c|}
\hline \multicolumn{1}{|c|}{ Characteristics } & Testing method & $\begin{array}{c}\text { Quality } \\
\text { demands }\end{array}$ \\
\hline Density, $\mathrm{g} / \mathrm{cm}^{3}$ & SRPS ISO 2781:1997 & $1.15 \pm 0.03$ \\
\hline Hardness, $\mathrm{H}^{\circ} \mathrm{ShA}$ & SRPS ISO 7619-1:2014 & $65 \pm 5$ \\
\hline Abrasion, $\mathrm{mm}^{3}$ & SRPS ISO 4649:2014 & $\operatorname{max135}$ \\
\hline Tensile strength, $\mathrm{N} / \mathrm{mm}^{2}$ & SRPS ISO 37:2004 & $\min 12$ \\
\hline Tensile elongation, $\%$ & SRPS ISO 37:2004 & $\min 280$ \\
\hline Tearing resistance, $\mathrm{N} / \mathrm{mm}$ & SRPS ISOG.S2.735 & Min 27 \\
\hline
\end{tabular}

\section{Results and Discussion}

In this paper, we tested the characteristics of a sole made of an elastomeric material (sample 1), a sole made of a combined rubber and polyurethane material (sample 2) and a sole made of a thermoplastic elastomer material (sample 3). The test results are given in Table 3.

Table 3 - Results of testing the soles

Таблица 3 - Результаты испытаний подошв

Табела 3 - Резултати испитивања ђонова

\begin{tabular}{|c|c|c|c|c|c|}
\hline Characteristics $^{*}$ & Testing method & $\begin{array}{c}\text { Quality } \\
\text { demands }\end{array}$ & $\begin{array}{c}\text { Sample } \\
1\end{array}$ & $\begin{array}{c}\text { Sample } \\
2\end{array}$ & $\begin{array}{c}\text { Sample } \\
3\end{array}$ \\
\hline Density, $\mathrm{g} / \mathrm{cm}^{3}$ & $\begin{array}{c}\text { SRPS ISO } \\
2781: 1997\end{array}$ & $1.15 \pm 0.03$ & 1.25 & 1.13 & 1.16 \\
\hline Hardness, $\mathrm{H}^{\circ} \mathrm{Sh} \mathrm{A}$ & $\begin{array}{c}\text { SRPS ISO } \\
7619-1: 2014\end{array}$ & $65 \pm 5$ & 70 & 70 & 75 \\
\hline Abrasion, mm ${ }^{3}$ & $\begin{array}{c}\text { SRPS ISO } \\
4649: 2014\end{array}$ & $\max 135$ & 93.8 & 142 & 78 \\
\hline $\begin{array}{c}\text { Tensile strength, } \\
\mathrm{N} / \mathrm{mm}^{2}\end{array}$ & $\begin{array}{c}\text { SRPS ISO } \\
37: 2004\end{array}$ & $\min 12$ & 11 & 11.6 & 8.3 \\
\hline $\begin{array}{c}\text { Tensile elongation, } \\
\%\end{array}$ & $\begin{array}{c}\text { SRPS ISO } \\
37: 2004\end{array}$ & $\min 280$ & 550 & 775 & 450 \\
\hline
\end{tabular}




\begin{tabular}{|c|c|c|c|c|c|}
\hline Characteristics* & Testing method & $\begin{array}{c}\text { Quality } \\
\text { demands }\end{array}$ & $\begin{array}{c}\text { Sample } \\
1\end{array}$ & $\begin{array}{c}\text { Sample } \\
2\end{array}$ & $\begin{array}{c}\text { Sample } \\
3\end{array}$ \\
\hline $\begin{array}{c}\text { Tearing resistance, } \\
\text { N/mm }\end{array}$ & $\begin{array}{c}\text { SRPS ISO } \\
\text { G.S2.735 }\end{array}$ & $\min 27$ & 39.8 & 33 & 53.4 \\
\hline $\begin{array}{c}\text { Resistance } \\
\text { to bending } \\
\left(\begin{array}{c}\text { De Mattia device, } \\
130.000 \text { cycles })\end{array}\right.\end{array}$ & $\begin{array}{c}\text { SRPS ISO } \\
123: 2014\end{array}$ & No cracks & $\begin{array}{c}\text { No } \\
\text { cracks }\end{array}$ & $\begin{array}{c}\text { No } \\
\text { cracks }\end{array}$ & $\begin{array}{c}\text { No } \\
\text { cracks }\end{array}$ \\
\hline
\end{tabular}

* Test specimens for testing the characteristics were clipped off from the sole samples.

The analysis of the quality requirements and the obtained results of testing the specimens have shown:

- The lowest wear value $\left(78 \mathrm{~mm}^{3}\right)$ occurs in sample 3 , while sample 2 has the highest one $\left(142 \mathrm{~mm}^{3}\right)$

- Samples 2 and 3 have almost the same tensile strength $\left(11 \mathrm{~N} / \mathrm{mm}^{2}\right.$ and $11.6 \mathrm{~N} / \mathrm{mm}^{2}$ ), while sample 1 has a significantly lower value of this property $\left(8.3 \mathrm{~N} / \mathrm{mm}^{2}\right)$,

- Sample 2 shows the highest elongation value (775\%), and sample 3 the lowest one $(450 \%)$,

- Splitting resistance, which can be seen as structural strength, is highest in sample $3(53.4 \mathrm{~N} / \mathrm{mm})$, and lowest in sample $2(33 \mathrm{~N} / \mathrm{mm})$,

- The results of testing resistance to bending, hardness and density are similar for all three samples of the tested soles.

\section{Conclusion}

The characteristics of the materials used in footwear industry are given, with a particular emphasis on polyurethane materials for making soles. The characteristics of the components are described as well as the basic chemical reactions, processing technology and the physical mechanical characteristics of this system.

The materials that can be used in footwear industry, primarily for the production of shoe soles, have been presented. Also discussed are the role, purpose and design of soles, as well as the requirements that this shoe part should satisfy.The manufacture of polyurethane soles by liquid injection molding technology (LIM technology) is presented, two of its procedures in particular: 
- The procedure of casting polyurethane material into the open tool and obtaining a sole as a component for further production, and

- The procedure of obtaining a sole directly by injecting polyurethane material onto the leather boot upper, which ends in a finished product.

The results of testing the specimens cut out from three sole samples show that almost all quality requirements from the technical specifications for this part of the shoe have been met.

The tested sole samples do not meet the formal requirements for tensile strength, although the values of this characteristic in the polyurethane-rubber sample and the elastomeric sample are very close to the set quality requirement.

The thermoplastic elastomer sole sample has a considerably smaller tensile strength and slightly higher hardness relative to the defined quality requirements for these two properties.

\section{References}

Bayer, O., 1947. Das Di-lsocyanat-Polyadditionsverfahren (Polyurethane). Angewandte Chemie, 59(9), pp.257-272. Available at: http://dx.doi.org/10.1002/ange.19470590901.

Groover, P.M., 2001. Fundamentals of moderen manufacturing: Materials, processes and systems, 4th ed.John Wiley \& Sons, Inc.

Melo, J.A., Cavaco, L.I., \& ed., 2012. Polyurethane: Properties, structure and applications.New York: Nova Science Publishers, Inc.

Mills, N.J., 2007. Polymer Foams Handbook: Engineering and biomechanics applications and design guide, 1st ed.Oxford: Butterworth - Heinemann.

Rosato, D.V., Rosato, M.G., \& Rosato, D.V., 2000. Concise encyclopedia of plastics.Norwell:Kluwer Academic Publishers.

- Urethanes Technology International, 2015. Light on their feet: PU helps sportsmen and workers. Urethanes Technology International, 32(3).

Yutaka, T., Buenaventurada, P.C., Charles, U.U., \& Seiichi, A., 2009. Biodegradability of plastics. International Journal of Molecular Science, 9, pp.3722-3742. Available at: http://dx.doi.org/10.3390/ijms10093722.

http://www.chemtrend.com/process/polyurethane_shoe/shoe_soling_polyurethane. Accessed: 15.03.2016.

http://www.essentialchemicalindustry.org/polymers/polyurethane.html. Accessed: 15.03.2016..

https://www.linkedin.com/pulse/one-material-rule-them-all-polyurethanefootwear-servet-casabona. Accessed: 15.03.2016.

http://www.medical.saint-gobain.com/sites/default/files/LSR-White-Paper_5-9-11_Jeff-Lefan.pdf. Accessed: 15.03.2016.. 
http://www.merriam-webster.com/dictionary/polymer. Accessed: 15.03.2016.

http://www.polyurethanes.org/uploads/images/durability.jpg. Accessed: 15.03.2016.

https://www.publications.theseus.fi/bitstream/handle/10024/97235/Thesis.p df?sequence=1. Accessed: 15.03.2016.

http://www.xiameter.com/en/ExploreSilicones/Documents/95-71601\%20LSR.pdf. Accessed: 15.03.2016.

ПОЛИУРЕТАНОВЫЕ И ЭЛАСТОМЕРНЫЕ ЧАСТИ ДЛЯ ПРОИЗВОДСТВА ОБУВИ МЕТОДОМ ПРЯМОГО ЛИТЬЯ ПОД ДАВЛЕНИЕМ

Радован М. Каркалич ${ }^{a}$, Йован Р. Радулович ${ }^{6}$, Далибор Б. Йованович

а Университет обороны в г. Белград, Военная академия,

г. Белград, Республика Сербия

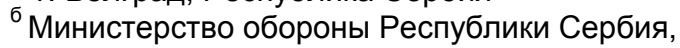

Военно-технический институт, г. Белград, Республика Сербия

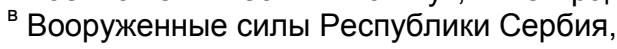

Опытно-экспериментальный технический центр,

г. Белград, Республика Сербия

ОБЛАСТЬ: химические технологии

ВИД СТАТЬИ: обзорная статья

ЯЗЫК СТАТЬИ: английский

Резюме:

В данной работе описаны характеристики материалов, используемых в производстве обуви, подчеркнута роль полиуретановых материалов в изготовлении подошв. Также описаны назначение, фрункция и конструкция подошвы, в том числе требования к качеству ее изготовления. Описаны производственные процессы полиуретановых подошв, изготовленных методом прямого литья под давлением (ЛИМ технология). В качестве иллюстрации приведено описание двух методов данной технологии. Первый метод подразумевает заливку полиуретана в открытую форму, а второй - жидкое формирование на затянутой заготовке верха обуви. Результаты анализа образцов, взятых с трех видов подошв, подтвердили соответствие требованиям к качеству, предписанных технической спецификацией по данному виду обуви. Несмотря на то, что испытанные образцы подошв фрормально не выдержали испытания на прочность, значения параметров образцов из комбинированного материала резина-полиуриетан и образцов из эластомерных материалов достаточно близки к установленным требованиям к качеству.

Ключевые слова: полимерные материалы, подошвы для обуви, технология прямого литья под давлением, качество. 
ПОЛИУРЕТАНСКИ И ЕЛАСТОМЕРНИ ДЕЛОВИ

ЗА ИНДУСТРИЈУ ОБУЋЕ ДОБИЈЕНИ

ТЕХНОЛОГИЈОМ ТЕЧНОГ ИЊЕКЦИОНОГ ОБЛИКОВАЊА

Радован М. Каркалић ${ }^{a}$, Јован Р. Радуловић ${ }^{6}$, Далибор Б. Јовановићв

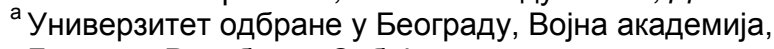

Београд, Република Србија

${ }^{б}$ Министарство одбране Републике Србије,

Војнотехнички институт, Београд, Република Србија

в Војска Србије, Технички опитни центар, Београд, Република Србија

ОБЛАСТ: хемијске технологије

ВРСТА ЧЛАНКА: прегледни чланак

ЈЕЗИК ЧЛАНКА: енглески

Резиме:

У раду су наведене карактеристике материјала који се користе у индустрији обуће, са посебним освртом на полиуретанске материјале за израду Ђонова. Размотрена је улога, намена и конструкција ђонова, као и захтеви које би овај део обуће требало да задовољи.

Описана је производња полиуретанских ђонова технологијом течног ињекционог обликовања (ЛИМ технологија). Описана су два поступка ове технологије. У првом се ђон добија уливањем полиуретана у отворени алат, а у другом директним убризгавањем полиуретана на горњиште обуће у затворени алат, чиме се завршава израда комплетне обуће.

Резултати испитивања епрувета, исечених из три узорка ђонова, указују на испуњење скоро свих захтева квалитета према техничкој специфрикацији за овај део обуће. Испитивани узорци Ђонова фрормално не задовољавају захтев за прекидну чврстоћу, мада су вредности ове карактеристике код узорка урађеног од комбинованог материјала гума-полиуретан и узорка од еластомерног материјала врло близу постављеног захтева квалитета.

Кључне речи: полимерни материјали, ђонови обуће, технологија течног ињекционог обликовања, квалитет.

Paper received on / Дата получения работы / Датум пријема чланка: 22.03.2016. Manuscript corrections submitted on / Дата получения исправленной версии работы / Датум достављања исправки рукописа: 09.12.2016

Paper accepted for publishing on / Дата окончательного согласования работы / Датум коначног прихватања чланка за објављивање: 11.12.2016. 
(C) 2017 The Authors.Published by Vojnotehnički glasnik / Military Technical Courier (www.vtg.mod.gov.rs, втг.мо.упр.срб). This article is an open access article distributed under the terms and conditions of the Creative Commons Attribution license (http://creativecommons.org/licenses/by/3.0/rs/).

(C) 2017 Авторы. Опубликовано в «Военно-технический вестник / Vojnotehničkiglasnik / MilitaryTechnical Courier» (www.vtg.mod.gov.rs, втг.мо.упр.срб). Данная статья в открытом доступе и распространяется в соответствии с лицензией

«CreativeCommons»(http://creativecommons.org/licenses/by/3.0/rs/).

(C) 2017 Аутори. Објавио Војнотехнички гласник / Vojnotehnički glasnik / Military Technical Courier (www.vtg.mod.gov.rs, втг.мо.упр.срб). Ово је чланак отвореног приступа и дистрибуира се у складу са CreativeCommonslicencom (http://creativecommons.org/licenses/by/3.0/rs/). 